\title{
Failure of Stainless Steel Welds Due to Microstructural Damage Prevented by In Situ Metallography
}

\author{
Juan Manuel Salgado Lopez ${ }^{1}$, María Inés Alvarado², Hector Vergara Hernandez³ , José Trinidad Perez Quiroz \\ Luis Olmos \\ 1 Centro de Ingeniería y Desarrollo Industrial, Querétaro, Querétaro, México. \\ 2 Instituto Tecnológico de Querétaro, Querétaro, Querétaro, México. \\ 3 Instituto Tecnológico de Morelia, Morelia, Michoacán, México. \\ 4 Instituto Mexicano del Transporte, Pedro Escobedo, Querétaro, México. \\ 5 Universidad Michoacana de San Nicolás de Hidalgo, Morelia, Michoacán, México.
}

Received: 25 Jan., 2016

Accepted: 21 Mar., 2016

E-mails:msalgado@cidesi.edu.mx (JMSL), maine.alvarado@hotmail.com (MIA), hvergarah@gmail.com (HVH), jtperez@imt.mx (JTPQ), luisra24@ gmail.com (LO)
This is an Open Access article distributed under the terms of the Creative Commons Attribution Non-Commercial License which permits unrestricted non-commercial use, distribution, and reproduction in any medium provided the original work is properly cited.

\begin{abstract}
In stainless steels, microstructural damage is caused by precipitation of chromium carbides or sigma phase. These microconstituents are detrimental in stainless steel welds because they lead to weld decay. Nevertheless, they are prone to appear in the heat affected zone (HAZ) microstructure of stainless steel welds. This is particularly important for repairs of industrial components made of austenitic stainless steel. Non-destructive metallography can be applied in welding repairs of AISI 304 stainless steel components where it is difficult to ensure that no detrimental phase is present in the HAZ microstructure. The need of microstructural inspection in repairs of AISI 304 is caused because it is not possible to manufacture coupons for destructive metallography, with which the microstructure can be analyzed. In this work, it is proposed to apply in situ metallography as non-destructive testing in order to identify microstructural damage in the microstructure of AISI 304 stainless steel welds. The results of this study showed that the external surface micrographs of the weldment are representative of HAZ microstructure of the stainless steel component; because they show the presence of precipitated metallic carbides in the grain boundaries or sigma phase in the microstructure of the HAZ.
\end{abstract}

Key-words: In situ metallography; Microstructure; Heat affected zone; Austenitic stainless steel; Welding.

\section{Emprego de Réplica Metalográfica na Prevenção de Falhas Devido a Danos Microestruturais em Soldas de Aço Inoxidável}

Resumo: Em aços inoxidáveis o dano microestrutural é causado pela precipitação de carbonetos de cromo ou de fase sigma. Estes microcomponentes são prejudiciais em soldas de aço inoxidável, porque eles levam a corrosão intergranular. No entanto, eles são propensos a aparecer na microestrutura da zona afetada pelo calor de soldas em aço inoxidável. Isto é particularmente importante para reparos de componentes industriais feitos de aço inoxidável austenítico. Réplica metalográfica pode ser aplicada para identificar a necessidade de reparos em componentes de aço AISI304 inoxidável onde é difícil assegurar que tal fase está presente na microestrutura da ZTA. A necessidade de inspeção microestrutural não destrutiva no aço inoxidável AISI 304 está associada a impossibilidade de se obter corpos de prova para análise via técnicas convencionais. Neste trabalho, propõe-se a aplicação de réplica metalográfica, a fim de identificar danos microestruturais em soldas de aço inoxidável AISI 304. Os resultados deste estudo mostraram que as micrografias da superfície externa do conjunto de peças soldadas representam a microestrutura da ZTA do componente de aço inoxidável porque mostram a presença de carbonetos metálicos precipitados nos contornos de grão ou de fase sigma.

Palavras-chave: Metalografia; Microestrutura; Zona afetada pelo calor; Aço inoxidável austenítico; Soldagem.

\section{Introduction}

Traditionally, "Metallography in situ" or "non-destructive metallography" has been carried out in components that work at critical temperatures, because this nondestructive test gives information about the mechanism of microstructural degradation in these type components. As an example, it can be mentioned the tubes exposed to direct fire that are applied in industrial boilers [1-3]. Because there is a close relationship between 
microstructure, mechanical properties and corrosion resistance in stainless steel, the microstructural damage of stainless steel can be evaluated through metallography [4-6].

Due to the application of austenitic stainless steel in the manufacture of components for the chemical, petrochemical and food industries, this work focuses on the study of microstructural damage in the heat affected zone (HAZ) of AISI 304 stainless steels, especially of components that need to be repaired by Tungsten Inert Gas welding (GTAW).

The arc welding process is applied to joint industrial components of austenitic stainless steel; this process involves the melting and solidification of a filler metal for joining two base metals [7]. This heating-cooling thermal cycle leads to localized phase transformations (heat affected zone: HAZ) in the base materials to join [8]. However, the welding process is also applied to repair damaged components, so microstructural damage can occur. However in repair welding, it is not a common practice to control the microstructural damage caused by this process.

Nondestructive tests are carried out on a component without affecting it; so they are used to ensure the overall quality of welded component [7]. But there is no nondestructive testing for assessing of HAZ microstructure in austenitic stainless steel free from detrimental microconstituents, which is very important for the integrity of welding in austenitic stainless steels to prevent unexpected failures that might result in production breakages or accidents [8-12]. The monitoring of the microstructure becomes critical; because in daily practice the process of repair by welding is carried out based on the welders' expertise, so there are cases where damage in the HAZ of the repaired component appears in a very short time [10-12].

In order to make clear the necessity of monitoring the state of the microstructure in stainless steel weldments, especially in the HAZ; the following case is shown because it illustrates the need for in situ metallography stainless steel welded joints. With this case it is demonstrated that this type of failure can happen after the welding process. In this case, chiller tubes made of AISI 304 austenitic stainless steel were welded and after it they were tested with the pressure test using common tap water. After a few days, those tubes showed leakages in areas adjacent to the weld. In the inner surface of the tubes was evidence of reddish corrosion products as seen in the Figure 1.

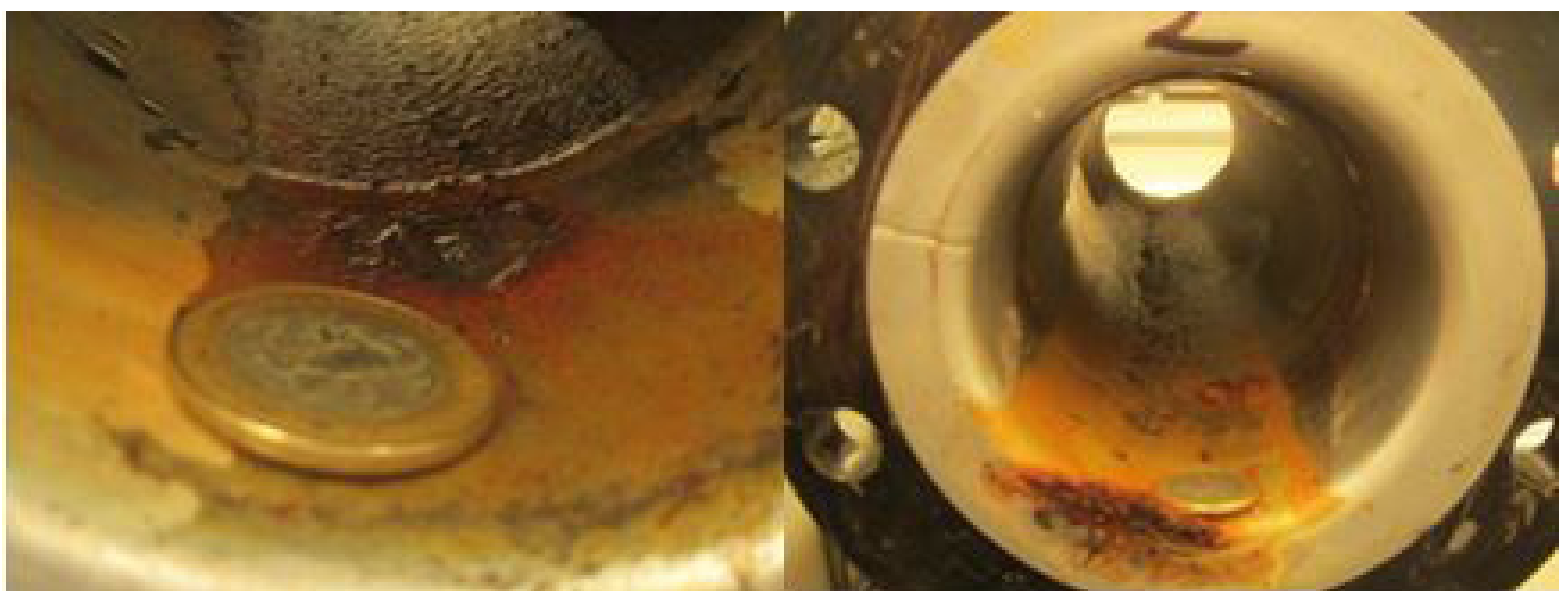

Figure 1. Damaged tubes of chiller under analysis. It is seen evidence of reddish corrosion products.

Figure 2 shows the failed tube where conventional metallographic inspections were carried out. In the same way, Figures $3 \mathrm{~A}$ and $3 \mathrm{~B}$ show the microstructure with corrosion damage, where metallic carbides and sigma phase are precipitated in the HAZ of this stainless steel weldment [9-13].

Pitting in the HAZ as well as a microstructure in this region with sigma phase and metallic carbides indicated that these microconstituents in conjunction with the chlorine and sulfur of the tap water, which was housed inside this tube, caused the leakages due to corrosion. In literature, as in this case, it has been demonstrated that failures in stainless steel weldments are related to corrosion in the HAZ and they are referred as "weld decay". 

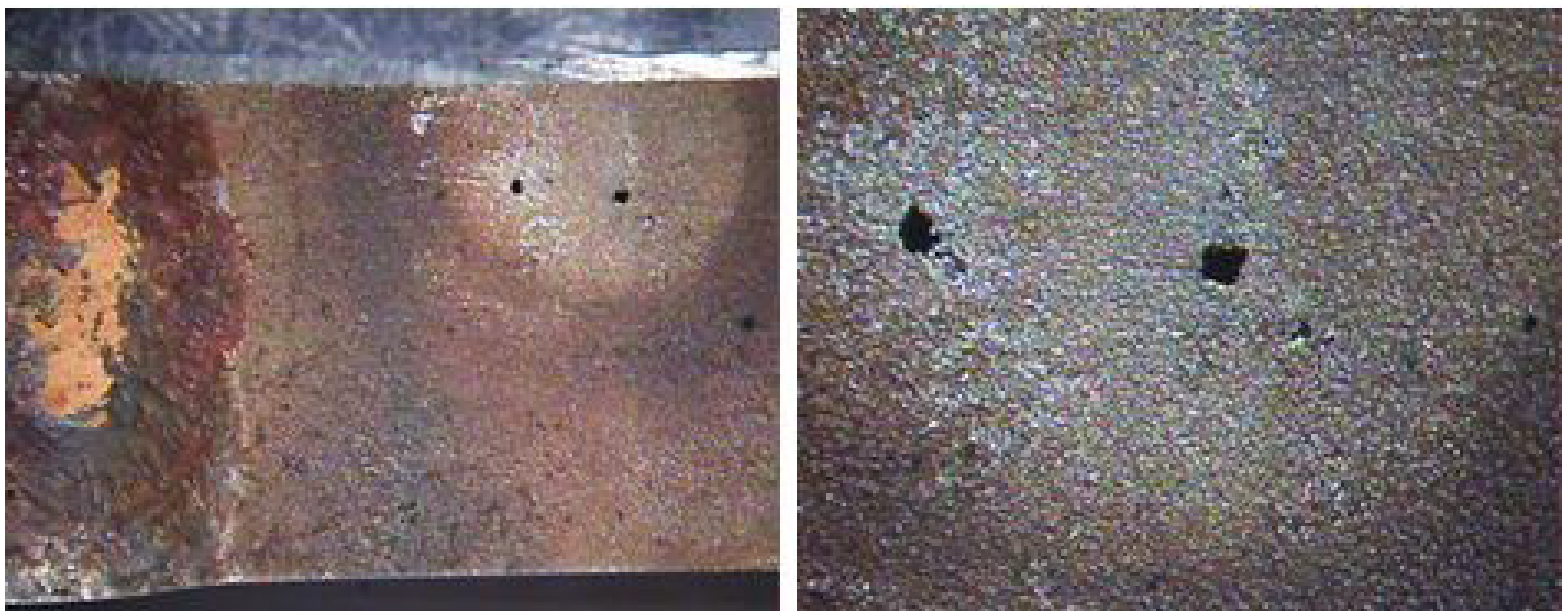

Figure 2. Internal surface of the damaged tubes after cleaning. There can be seen corrosion pitting near the weld metal.

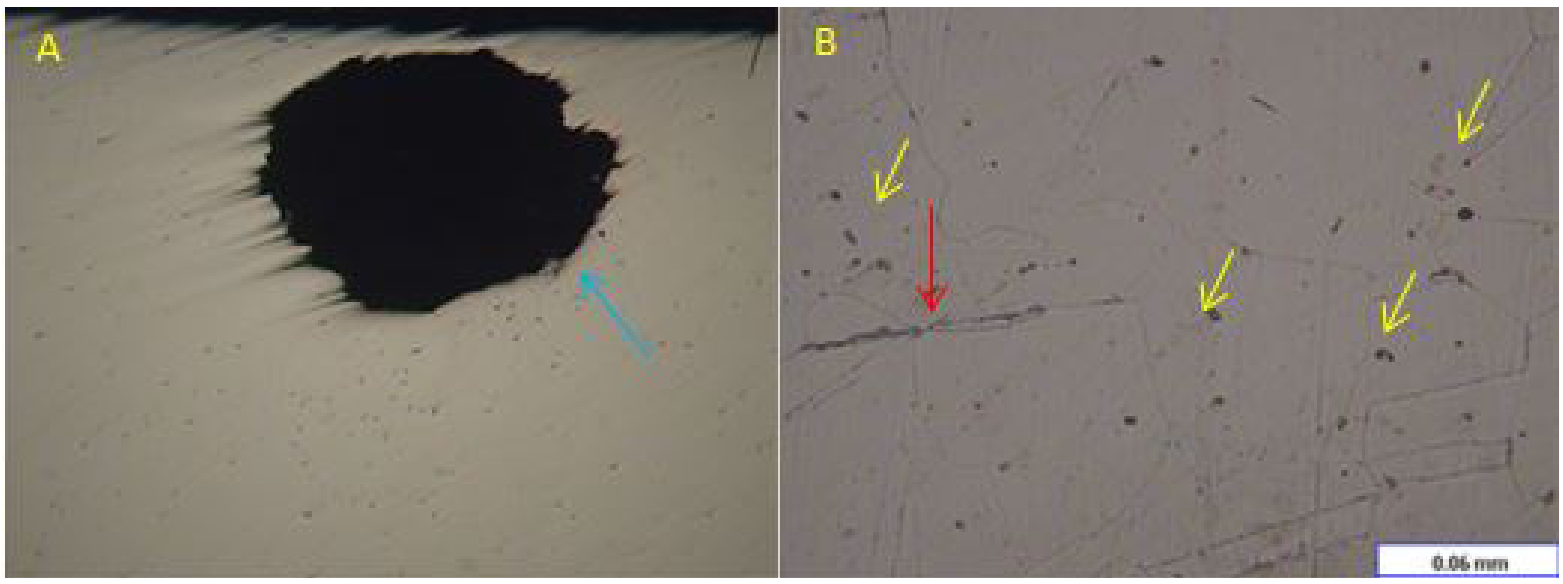

Figure 3. A - Image at 100x of a cavity produced due to corrosion (blue arrow). B - Microstructure in the HAZ of the welding at 500X. Twined grains with sigma phase (red arrow) and metallic carbides (yellow arrow) are seen.

In this case, in situ metallography could be applied in welding stainless steel to determine the microstructural integrity of welded joints of stainless steel and to avoid the failure of the component.

\section{Objective}

The objective of this work is to reveal the microstructure in the HAZ of AISI 304 stainless steel weldments applying in situ metallography and to compare the microconstituents showed with this technique with the microstructures seen with conventional laboratory metallography. This comparison is carried out in order to define in situ metallography as capable to reveal detrimental microconstituents in the HAZ that led to weld decay.

\section{Methodology}

The experimental technique followed for the authors is explained in this section. The materials utilized in this work were AISI 304 austenitic stainless steel as base material and 309S stainless electrodes as filler metal (ER 309L). The typical chemical compositions of these materials are shown in Table 1; but the chemical compositions were verified by quantitative chemical analysis with an optical emission spectrometer Espectrolab Lav MB 18B, SPECTRA A 220. 
Table 1. Chemical composition of steel AISI 304 and 309L ER filler.

\begin{tabular}{|c|c|c|c|c|c|c|c|c|c|c|}
\hline & C & Mn & Si & $\mathbf{P}$ & $\mathbf{S}$ & $\mathrm{Cr}$ & $\mathbf{N i}$ & Mo & $\mathbf{N}$ & otros \\
\hline $\begin{array}{l}\text { AISI } \\
304\end{array}$ & 0.08 & 2.00 & 1.00 & 0.045 & 0.030 & $18.00-20.00$ & $8.00-10.00$ & ---- & ---- & $\ldots$ \\
\hline $\begin{array}{l}\text { AISI } \\
\text { ER 309L }\end{array}$ & 0.03 & ---- & ---- & ---- & ---- & $23.00-25.00$ & $12.00-14.00$ & ---- & ---- & \\
\hline
\end{tabular}

Plates of stainless steel AISI 304 were cut with the following dimensions: $152 \times 72 \times 5.20 \mathrm{~mm}$. A schematic diagram of the preparation groove of the base material is shown in Figure 4. Due to evidence of carbide precipitation in the microstructure of the "as delivery" base material, it was necessary to carry out a carbide solution heat treatment at $1100{ }^{\circ} \mathrm{C}$, before it could be welded.

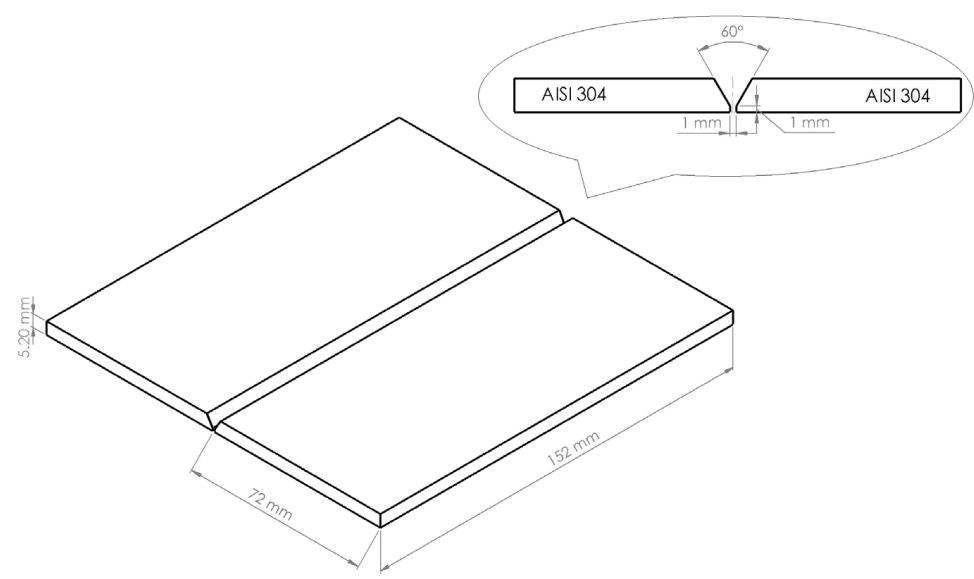

Figure 4. Diagram of the preparation of the base materials.

First, four stainless steel samples were welded through automatized GTWA. After welding, they were inspected by no destructive techniques. Then, in order to simulate a welding repair, the welded specimens were manually welded utilizing GTWA process. The welding conditions are shown in Table 2.

Table 2. Variables of automatized GTAW process.

\begin{tabular}{cccccc}
\hline Base material: & AISI 304 L & Sample's legth & $152 \mathrm{~mm}$ & thickness & $5.20 \mathrm{~mm}$ \\
Filler metal: & ER 309L Si & $\begin{array}{c}\text { Electrode diameter } \\
\text { Current: } 170 \mathrm{~A}\end{array}$ & $\begin{array}{c}0.889 \mathrm{~mm} \\
\text { Feed: } 20 \mathrm{~m} / \mathrm{min}\end{array}$ & $\begin{array}{c}\text { Shielding Gas } \\
\text { Voltage 12V. }\end{array}$ & Ar \\
\hline
\end{tabular}

The specimens were inspected through magnifying glasses to determine its surface condition and the general characteristics of the discontinuities exhibited on the weld seam of the 4 specimens. As it is shown in Figure 5 no discontinuities welding as undercuts, arc strikes, splashes or other type of discontinuities were observed. 


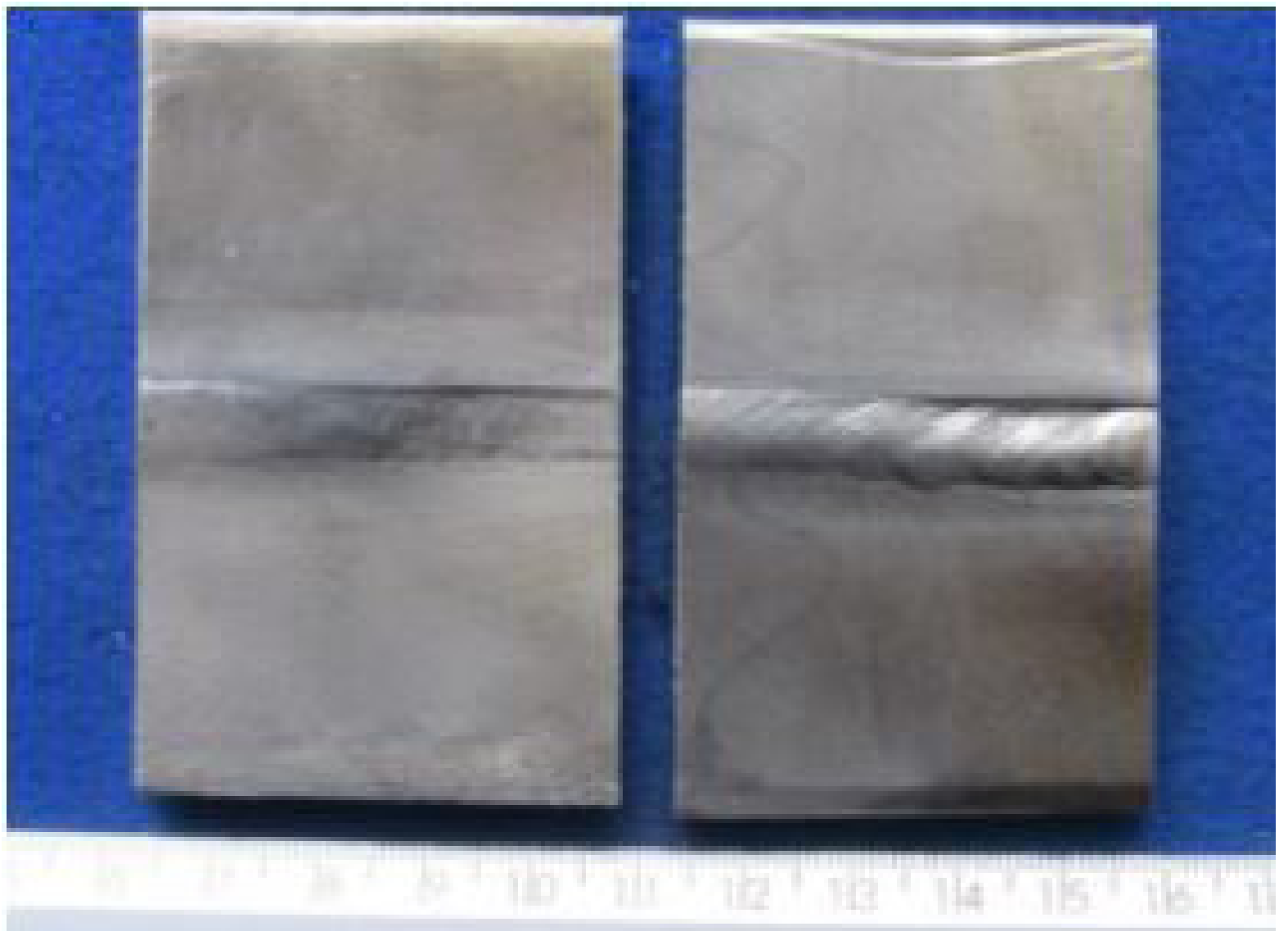

Figure 5. Visual testing of the welded joints after GTAW process.

The welded specimens were inspected through visual testing and $X$-ray radiography. The equipment was a $V$ tube X-IT, and the conditions were: $175 \mathrm{kV}$ power, current of $5 \mathrm{~mA}, 40 \mathrm{~cm}$ and with an exposure time of $60 \mathrm{sec}$. Figure 6 shows discontinuities such as: Tungsten inclusions (yellow arrows) and lack of fusion (red arrows) that were found in one of the welded samples.

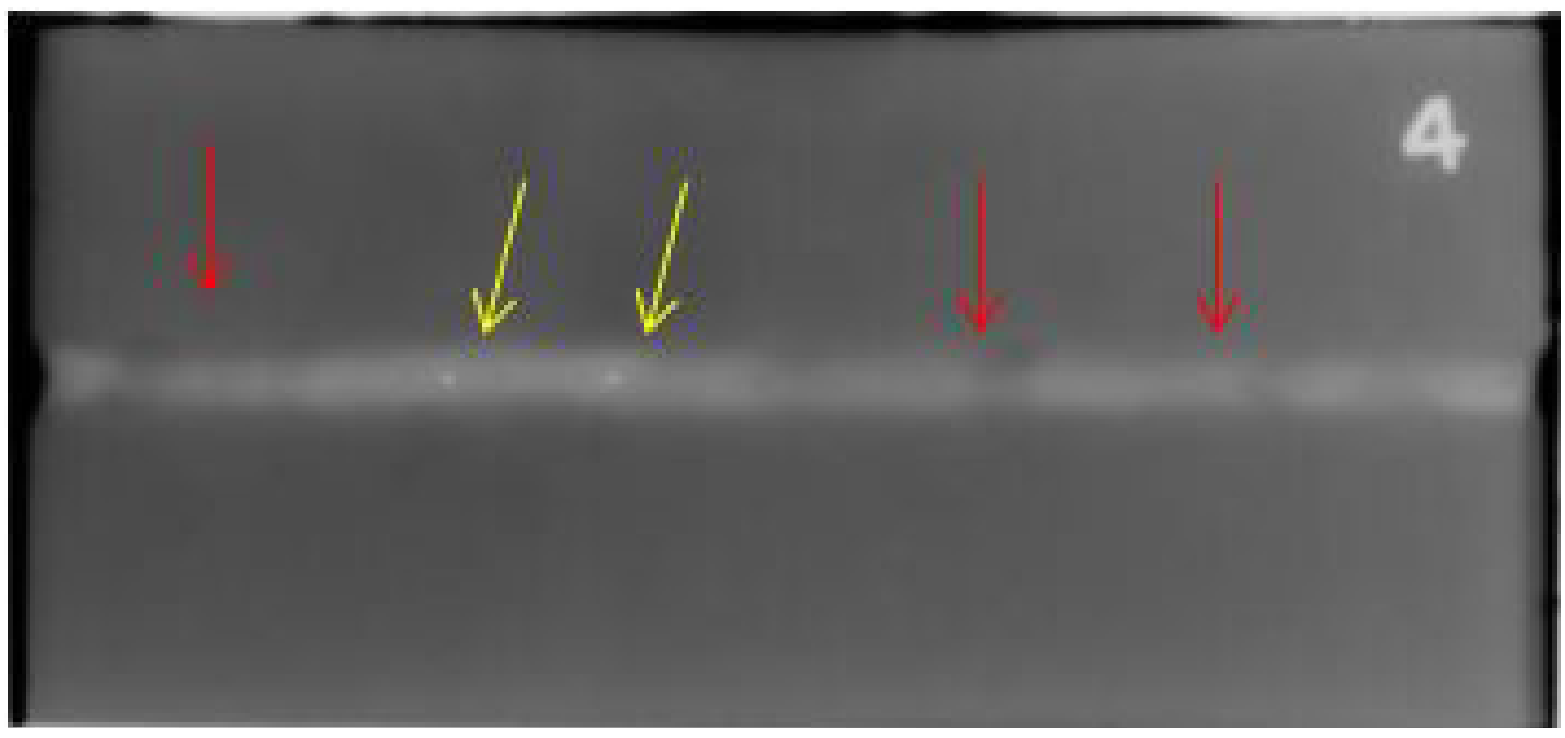

Figure 6. Results of the X-ray radiography of one welded joint for repairing. 
The welding repairs were carried out selecting the area of interest and then this area of the welded specimen was grinded by abrasive silicon carbide disc. After that, they were grinded for repairing in the locations that the nondestructive testing showed evidence of indication. The specimens were welded through manual GTAW process. One example of the repairs is shown in Figure 7. The welding conditions were: ER 309L electrode with a wire diameter $\varnothing=1 / 32$ as filler metal, a Syncrowave 350Lx Miller welding machine; and welding current around 70A.

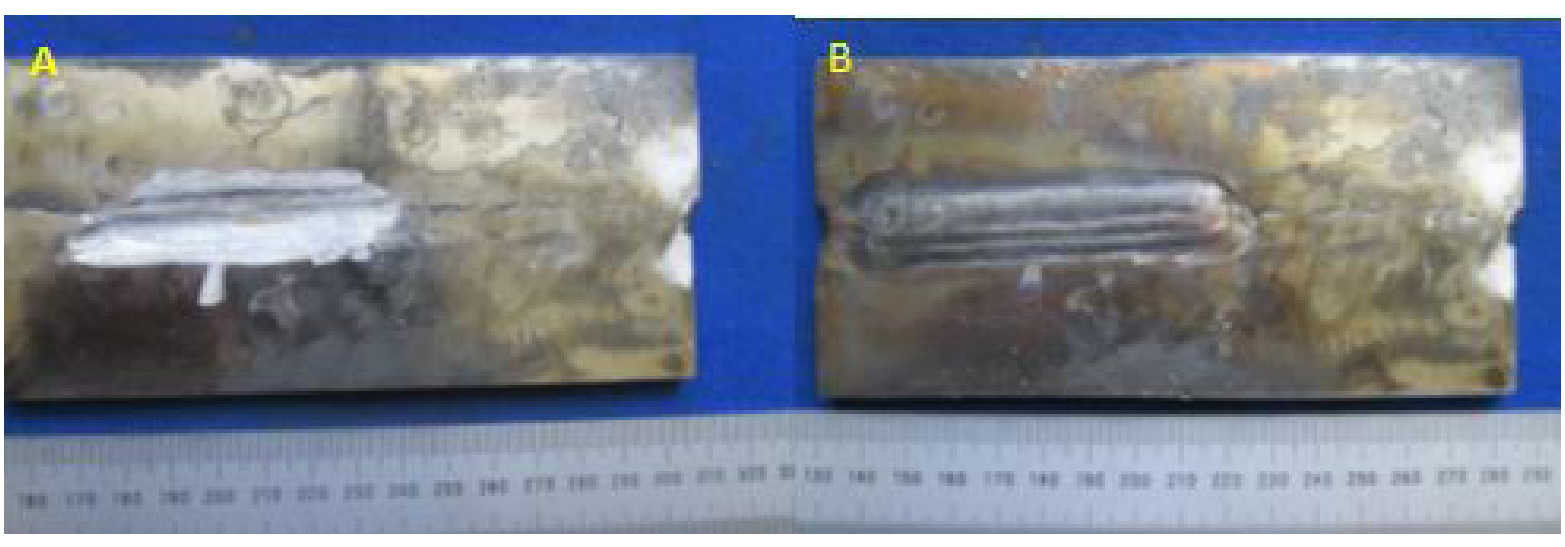

Figure 7. A - Example of the specimens after mechanical grinding in the weld metal. B - Example of the repaired areas of the specimen through manual GTAW.

Before, the repaired specimens were prepared for in situ metallography; the welding reinforcement was removed by grinding. The external surfaces of the HAZ in welded joints were prepared for in situ metallography. In order to reveal the microstructure the location, it was chemical etched with a solution of $15 \mathrm{ml} \mathrm{HCl}, 10 \mathrm{ml} \mathrm{HF}$, HNO3 $10 \mathrm{ml}$, and 3 drops of glycerin, using a swab [14-16]. These microstructures were observed using a Struers DIN WF 10X / 18 field microscope and photographs were taken with Canon Power Shot A3400 IS HD camera.

Finally after the nondestructive metallography, these specimens were cut in the area of the in situ metallography in order to be prepared for conventional laboratory metallography the transversal area of the welded joints following ASTM E3-11 [14]. The microstructures were revealed by electrochemical etching, which was carried out with oxalic acid 10\% (100ml distilled water and $10 \mathrm{~g}$ oxalic acid.) [15,16]; in a Buehler electromet during 50 seconds and with 4V. The observation was made on a brand NIKON EPIPHOT 200 optical microscope image analyzer.

\section{Results and Discussion}

The microstructure of the base material "as delivery" was revealed applying in conventional metallography (Figure 8A) and in situ metallography (Figure 8B). The microstructure of the stainless steel AISI 304 showed a highly sensitized twinned structure, because there was evidence of chromium carbides precipitated along bands in the direction of cold rolling process. In both cases metallic carbides precipitates in the twinned grains area seen. These microconstituents indicated that the base material must be heat treated in order to dissolve the chromium carbides to prevent failures. Both microstructures showed the same characteristics even when each samples were observed in different planes and they were revealed by different etching methods. These facts indicated that in situ metallography can be applied to identify the metallurgical state of the base material.

Nevertheless, they are differences between the microstructures showed previously; for instance, no evidence of banding can be seen with the in situ metallography. This can be explained by the fact that the microstructure revealed though in situ metallography on the HAZ laid on the perpendicular plane to the thickness of the plate, which is the external surface of the material base. AISI 304 stainless steel with a microstructure that shows precipitated metallic carbides should not be welded because the heat input will make susceptible the material to corrosion. So then, after performing the solution heat treatment, the microstructure must consist on twinned grains with a low amount of metallic carbides, especially those related to TiC and MoC $[3,4,8,10,11]$. 

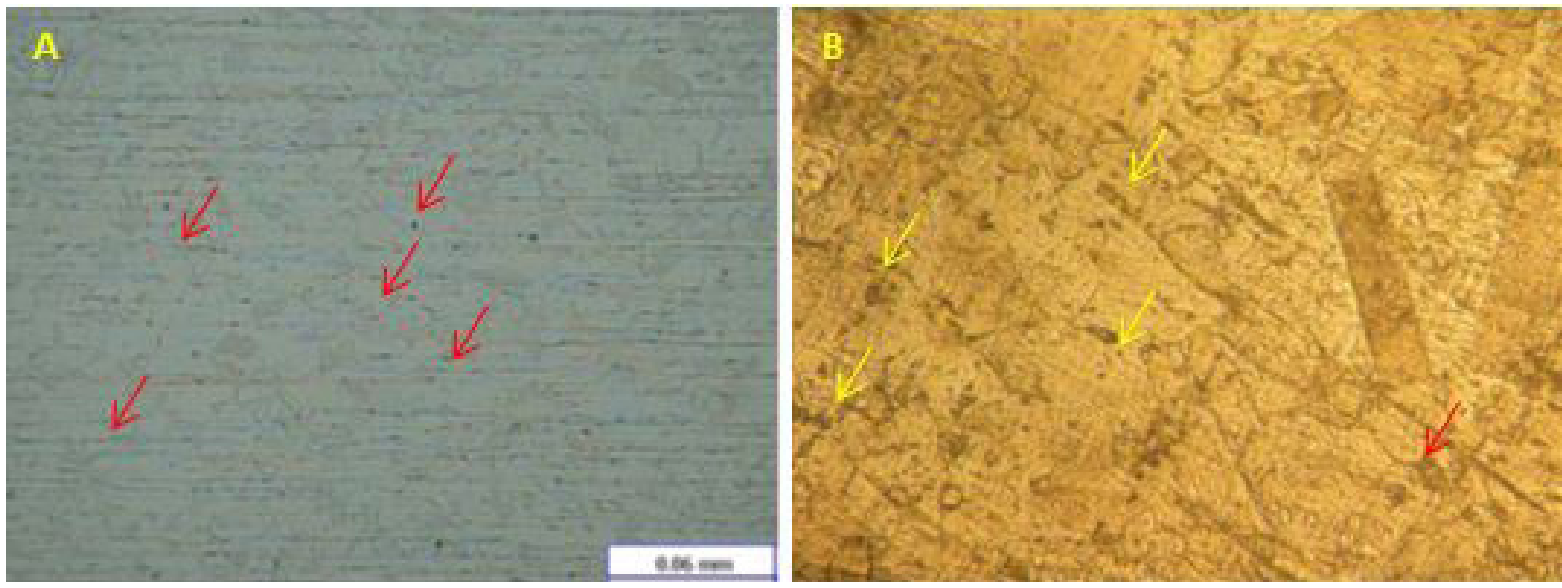

Figure 8. A - Microstructure at 200x shows the microstructure of the base material prepared by conventional metallography. B - Microstructure at 200x shows the microstructure of the base material prepared by in situ metallography.

Figures 9A and 9B show the microstructures of the base material after heat treatment. In this case, both microstructures are comparable to each other and both of them showed qualitative evidence of a reduction in the amount of metallic carbides and grain growth, which indicates that solution heat treatment was succeed and the risk of weld decay was reduced.

In the production of welded components discontinuities such as: lack of fusion or tungsten inclusions must be removed and repaired. Then in this case the defects were removed through grinding. Because during welding repair, this area of the specimen is subject to temperatures high enough to produce microstructural changes, it is necessary to inspect it by metallography. One has to keep in mind that in our case a relative high welding current was applied in order to induce metallurgical damage in HAZ.

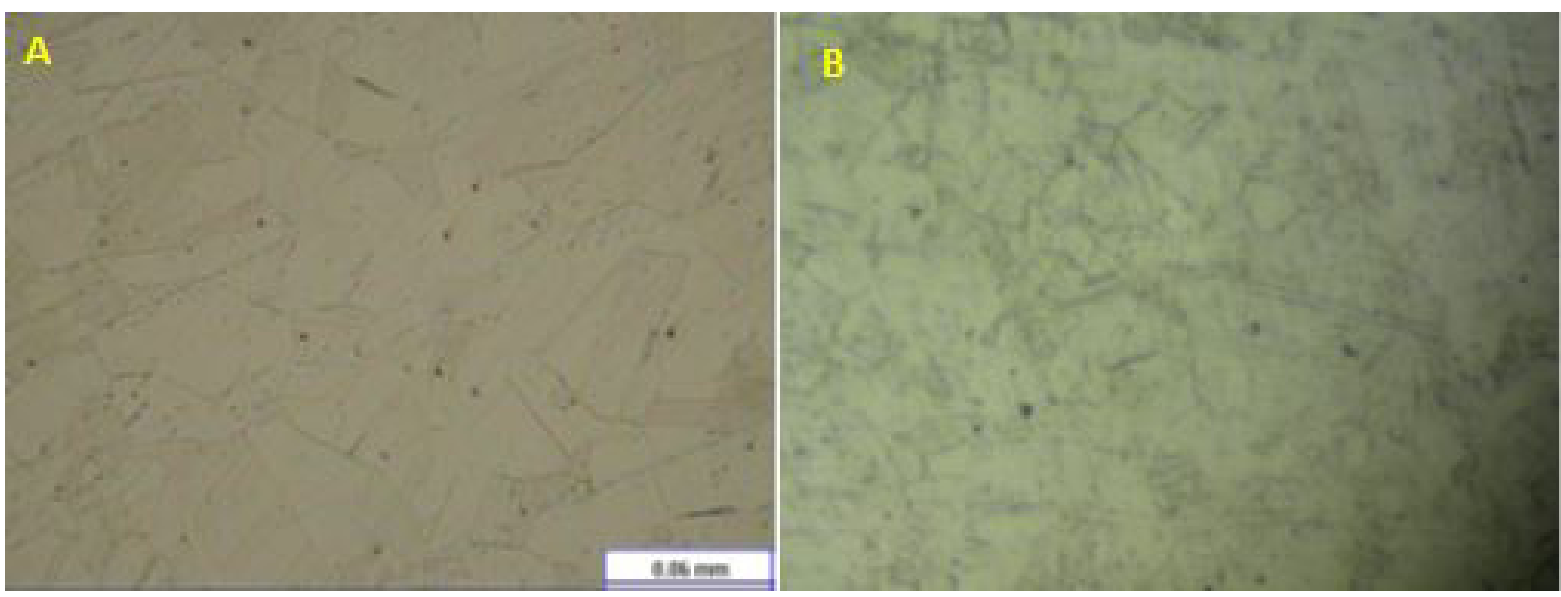

Figure 9. A - Microstructure at 200x of the base material subsequent to solution treatment carbides prepared by conventional metallographic. B - Microstructure at 200x revealed through in situ metallographic of the AISI 304 stainless steel after being subjected to a solution treatment of carbides.

In Figures $10 \mathrm{~A}$ and $10 \mathrm{~B}$, the microstructure in the HAZ of the one specimen after automatized welding is seen. Those micrographs evidences that both techniques, conventional metallography and in situ metallography, are able to show metallic carbides and sigma phase precipitated in the microstructure. However, conventional metallography is able to demonstrate that the sigma phase is mainly located in the middle of the specimen's thickness. This fact explains the reason of the low amount of sigma phase in the microstructure revealed though 

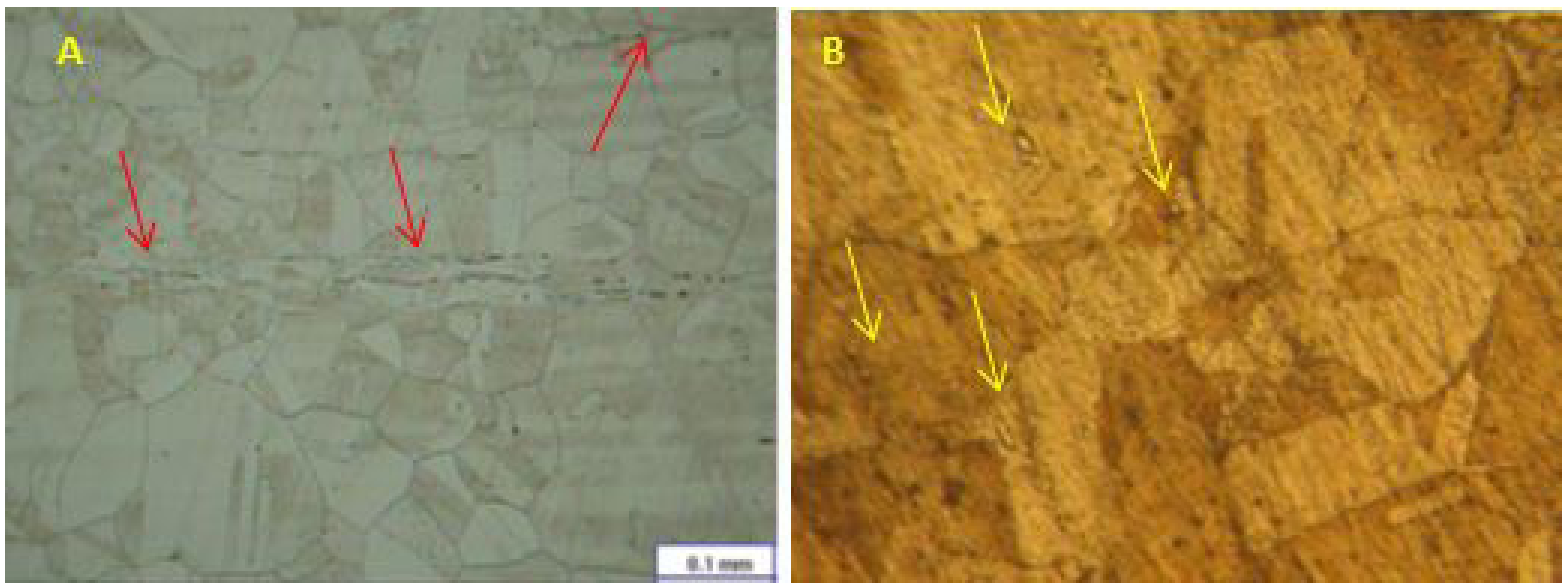

Figure 10. A - Microstructure at 200x revealed through conventional metallography. B - Microstructure at 200x revealed though in situ metallography. Both microstructures show evidence of sigma phase and grain growth.

in situ metallography. In other words, the external surface of the specimen, where the in situ metallography was carried out, contains a lower amount of sigma phase.

In Figures $11 \mathrm{~A}$ and $11 \mathrm{~B}$, the microstructure in the $\mathrm{HAZ}$ of one of the specimens after welding repair is seen. The microstructure revealed though conventional metallography shows a higher amount of sigma phase than in the microstructure of the automatized welding. This fact indicated that the heat input of the welding repair increased the precipitation of this phase, which is detrimental for AISI 304 stainless steel.

It must be explained that the quality of the in situ metallography micrograph cannot be as good as conventional metallography due to the differences in the preparation technique; moreover the first microstructure was revealed through electroetching and the second one was revealed using gliceregia.

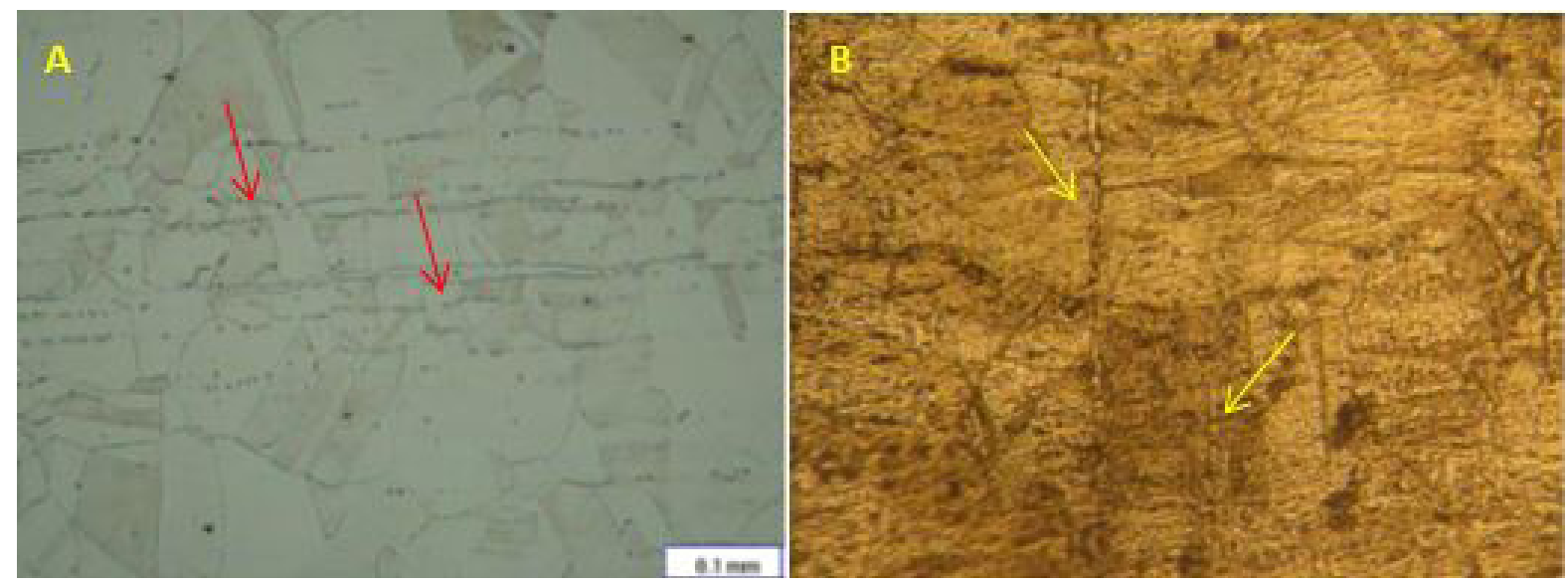

Figure 11. A - Microstructure at 200x revealed though conventional metallography. B - Microstructure at 200x revealed though in situ metallography.

In literature it has been probed that sigma phase caused sensitization of the passive layer, which induces corrosion in the material $[3,8-10]$. Moreover, this phase is brittle; so then, microstructures of this type stainless with sigma phase under cyclic loads will be susceptible to fatigue cracking. The fact that in situ metallography is capable to show the existence of sigma phase, grain growth, and precipitated metallic carbides probes that this technique can be applied for reveling metallurgical damage in welded stainless steel. This is especially important in case of welding repairs. 
The present work demonstrates that in situ metallography is able to detect metallurgical damage in the HAZ microstructure of AISI 304 stainless steel base materials with precipitated sigma phase and metallic carbides. In case of projects where the process is able to be qualified, the conventional metallographic technique is the best option. Nevertheless, one has to bear in mind that in the field, welding is carried out by humans and normally using SMAW process. Then, components made of stainless steel will be prone to weld decay if, for example, the welder reduces the traveling speed (as it occurred in the case explained earlier in this work). In such case it might be worthy and useful to applied in situ metallography in HAZ in order to evaluate the microstructure after welding.

Furthermore, where there is the need of repairing by welding components made of stainless steel, this technique is very useful for evaluating the integrity of a welded component in order to prevent failures on the repaired components in a short time, which can lead to accidents. So, based on the results previously shown, in situ metallography is proposed as a non-destructive test for inspect weldments and welding repairs of stainless steel.

\section{Conclusions}

The previously discussed results of this work led to the following conclusions:

a) It is very important to assess the microstructural integrity of welded components made of AISI 304 stainless steel in order to prevent failures of welded joints due to weld decay.

b) The microstructures revealed through in situ metallography are qualitatively comparable with the microstructures revealed through conventional metallographic technique.

c) There are differences between the microstructures revealed through in situ metallography and the microstructural because the differences in etchant and planes of preparation in the specimens.

d) In situ metallography is able to detect detrimental microconstituents in the HAZ of the austenitic stainless steel, such as precipitated metallic carbides or sigma phase.

e) This study demonstrated that in a weld, the monitoring of the microstructure in the heat affected zone can be carried applying in situ by metallography.

\section{Acknowledgements}

The authors would like to thank to Laboratorio de Metalografía y Análisis de Falla for the technical support and Laboratorio Nacional de Investigación en Tecnologías del Frío de CIDESI sede Querétaro for the financial support during this research.

\section{References}

[1] Stork Herron Testing Laboratories. White paper: In situ metallography: When there's no other way. Clevand; 2010. p. 3.

[2] Penny RK. Ageing of materials and methods for the assessment of lifetimes of engineering plant. Rotterdam: Balkema; 1997. p. 48.

[3] Port RD, Herro HM. The Nalco guide to boiler failure analysis. New York: McGraw-Hill; 1991. p. 243-244.

[4] Lippold JC, Kotecki DJ. Welding metallurgy and weldability of stainless steels. Hoboken: Wiley-Interscience; 2005. p. 141-168.

[5] Davis JR. Corrosion of weldments. Materials Park: ASM International; 2006. p. 49-183.

[6] Cramer SD, Covino BSJr, editors. Corrosion: fundamentals, testing, and protection. Materials Park: ASM International; 2003. p. 266-274, p. 661, p. 751. (ASM Handbook, vol. 13A).

[7] Kuo S. Welding metallurgy. Hoboken: John Wiley and Sons; 2006.

[8] Davis JR. Stainless steel. Materials Park: ASM International; 1999. p. 5-13, p. 146-147.

[9] Villalobos DR. Precipitación de la fase sigma bajo la aplicación de ciclos térmicos en un acero inoxidable superdúplex SAF 2507 [tesis de doctorado]. Morelia: Instituto de Investigaciones Metalúrgicas; 2011. p. 6.

[10] KhatakHS, Raj B. Corrosion of austenitic stainless steels: mechanism, mitigation and monitoring. India: Alpha Science; 2002. p. 10-24. http://dx.doi.org/10.1533/9780857094018.

[11] Montenegro JJ. Studio de la soldadura en aceros austeníticos. Perú: Universidad de Pirhua; 2005, p. 21.

[12] Radhakrishnan VM. Welding technologyand design aspects of welding. England: Abigton Publishing; 2005. p. 21.

[13] ASTM International. Standard test methods for tension testing of metallic materials. West Conshohocken:American Society for Testing Materials; 2011.

[14] Vander Voort GF. Metallography: principles and practice. New York: McGraw-Hill; 1984. p. 60-75.

[15] Vander VoortGF. Metallographyand microstructures. Materials Park: ASM International; 2004. p. 589-725. (ASM Handbook, vol. 9).

[16] GeelsK. Metallographic and materialographic specimen preparation, light microscopy, image analysis and hardness testing. West Conshohocken: ASTM International; 2007. p. 528-555. http:// dx.doi.org/10.1520/MNL11195M. 